\title{
Teaching to understand a written text as a methodical problem
}

\author{
Liliya Gromova ${ }^{1}$, Irina Tekucheva ${ }^{1}$, Anna Shmeleva ${ }^{2, *}$ \\ ${ }^{1}$ Moscow Pedagogical State University, 1/1, Malaya Pirogovskaya str., 119991, Moscow, Russia \\ ${ }^{2}$ Moscow Region State University, 10A, Radio str, 105005, Moscow, Russia
}

\begin{abstract}
The article deals with one of the most important problems in modern methodology: the problem of teaching to understand a written text. We discuss characteristics of such concepts as "understanding", "perception" and "text", as well as offer classifications of the structure of understanding. The article renders an analysis of techniques of understanding and their classification in relation to the lessons of the Russian language where analytical reading is taught. The article also presents a system of exercises focused on attentive reading and deep understanding.
\end{abstract}

\section{Introduction}

Understanding is a prerequisite for communication, productive and reproductive text work. Therefore, research into the development of effective methods for forming comprehension skills is an important methodological task. In order to understand a text, it is necessary to read it correctly first. The deficiency in reading comprehension and information processing skills make it difficult for school children to create secondary texts or create their own works. The lack of text comprehension skills can also result in a failure to complete assignments in different school subjects. That is why teachers and methodologists face the necessity to improve approaches to teaching text comprehension.

The relevance of the presented research is connected with the shortcomings of the current methods used to teach text comprehension. For this reason, it seems important to develop effective methods for improving and forming text comprehension skills.

\section{Discussion}

Let us take the concepts of text, understanding and perception. A text is a unit of communication, a product of speech activity [1]. Having a number of common properties texts can significantly differ in their perception characteristics and degree of interpretability.

For L.A. Zimnyaya, the process of text understanding is the perception of meaning. Text reading is viewed upon as a close relationship between perception and understanding

\footnotetext{
*Corresponding author: lug-anna@yandex.ru
} 
since understanding is a two-sided process. On the one hand it is a process of "sensual reflection of reality", on the other hand - a process of indirect perception of meaning [2]. N.I. Zhinkin represents the process of understanding and perception as an organized system of several levels, with perception being the lowest level and comprehension being the highest level [3].

M.M. Bahtin viewed understanding as the second stage of knowledge acquisition coming after text perception. The process of understanding is a hierarchical structure with two levels: the level of meaning and the level of sense which come into being only after perception and information processing. Text understanding starts with the comprehension of the simpliest units and finishes with a deeper understanding which includes interpretation [4]. Following this conception text understanding requires going beyond its literal reading and can be determined as its interpretation by correlation with other texts, personal perception, interpretation and a cultural context. M.M. Bahtin calls understanding a "dialogue movement" which involves three stages. The starting point of this process is the text to be read. While getting acquainted with the source of information there may be a movement forward, that is "anticipation (and the beginning) of the future context, or a backward movement - a reference to prior knowledge. According to M.M. Bahtin understanding is built upon a combination of many interpretations each of which is formed on all three levels. Such kind of movement results in a deep immersion into the meaning of the text

Understanding is a process of recoding of text information. A transition from the linear structure of the text to its meaning is the result of a number of actions focused on a deeper reading comprehension. An adequate information intake is a transition from the surface language form of the text to its meaning. In the process of understanding students form one or several models based on personal perception, initial information and characteristics of the outer, inner and imaginary worlds [5].

When he was setting criteria to assess the degree of text comprehension, I.F. Annenskij distinguished several types of understanding: grammatical (understanding of grammatical forms and grammatical links between words), logical (understanding of correct thoughts connection), esthetic (understanding of expression, the beauty of lexicon, phrases, scenes, episodes and whole literary works), historical (understanding of the place of the word, phrase, motive and the whole piece of writing) [6].

G.I. Bogin wrote about three levels of text understanding. The first level gives semantic understanding that is "decoding of text units carrying a linguistic sign function". This process becomes necessary in case of text perception difficulties in the course of language study when a "new word" should be explained. The second level of understanding is cognitive. It is reached when all the problems with the perception of new information are solved, when the content of the text is comprehended. After this level the students must establish links between segments of information, make conclusions and generalizations. On the third level (a non-object one) the reader converts the information into personal meaning, which is the process of text interpretation [7].

We determine understanding as a processual multilevel phenomenon, the highest step of information processing, which has qualitative characteristics, such as sense and meaning. Sense reflects an objective side of the phenomenon, and meaning reflects its subjective side that is "personal meaning". Under the objective point of view we understand the author's position, a system of images a reader refers to in the process of text perception. It is the reader's task to bring his or her understanding closer to the author's intent. However, we consider it impossible to reach an absolute concordance between the readers understanding of the text and the author's message. Understanding has a multi-level structure. Each level can be correlated with the stages of the process of understanding: 1) understanding of 
words - understanding of sentences - text understanding or 2) understanding of words correlation of bigger text units - text understanding [8].

Let us consider some particular techniques for developing understanding at Russian language lessons.

1. The first step to text comprehension is actualization of 'not understanding' (determination of incomprehension points), when the learners realize that they did not understand or misunderstood the text. The determination of incomprehension points can be represented in the form of the following scheme:

The process of reading ----- the result of the reading process: 1) understanding, 2) incomprehension, 3) misunderstanding ----- actualization of not understanding.

The process of reading can result in the understanding of what has been read, noncomprehension or misunderstanding. Being erroneously sure that they have understood the text, the learners cannot accept their mistakes and correct them. To avoid misunderstanding, it is necessary to realize that the text was not fully understood or was misunderstood.

The following tasks can be offered in the course of actualizing not understanding.

Task example. How do you understand the meaning of the word "water"? Make a word combination using this word in this meaning. The possible answers of the learners: 1) Clear, colourless liquid, a chemical combination of hydrogen and oxygen. River, spring water, Tap water, Sea water, a glass of water, 2) In some collocations: a drink or an extract. Cowberry water, Soda water, Mineral water, Fruit water, 3) pl. Seas, rivers, lakes, channels, straits belonging to a certain state, region, territory. Inland waters (within the boundaries of a state).

The appearance of several variants points to the necessity to define the notion of "water".

2. The second technique is the transformation of incomprehension into understanding. The process of transition can be described as follows: actualization of not understanding --- transition from incomprehension to understanding.

At this stage, the learners perform the following tasks: work with the dictionary article, make word combinations, find synonyms.

Task example. Read the dictionary article. The word "water" has several meanings: «WATER, 1. Clear colourless liquid, a chemical combination of hydrogen and oxygen. River, spring water. To pour water on someone's mill (fig.: to play into smb.'s hands). 2. In some collocations: a drink or an extract. Cowberry water, soda water, Mineral water, Fruit water, Rose water, Toilet water. 3. A mass or area of water, such as river, sea, lake and also their surface or level. To travel by water. High water (high water level). Big water (flood in wet season). Low water (its lowest level). To get the boat into the water. To go under water. To go by water. 4. pl. Seas, rivers, lakes, channels, straits belonging to a certain state, region, territory. Inland waters (within the boundaries of a state). Territorial waters (the area of sea belonging to a country). Neutral waters. 5. pl. 6. pl. Water from a spring, a resort with such waters. To take the waters to improve one's health. To go to the waters. Mineral waters. 7. fig. singular. About something without content, verbose (colloquial). The report had too much water. To pour water (about small talk). 8. pl. The liquid that surrounds a baby inside a pregnant woman's womb (special). Heavy water (special), water in which ordinary hydrogen atoms have been replaced by deuterium atoms. Yellow water - an old name of glaucoma. Dark water - blindness resulting from visual nerve disorder. Of the first water 1) about gems of the best quality. A diamond of the first water. 2) real, genuine. An idealist of the first water. To bring to clear water (colloquial) - to bring to light. Water animals (living in water). Water transport. Water stadium. Water vapor. Water bug. Watermark - a mark made in some types of paper that can only be seen if it is held against the light». 
Task №3. Find synonyms to the word "water" (water - liquid, drink, meaningless conversation).

3. The third technique for developing understanding is phenomenological reduction. This stage can include the following tasks:

Task №1. Find and underline key words in the text.

People are like rivers

"People are like rivers: with the same and similar water, but every river can be alternatively narrow, fast, wide, quiet, clean, cold, muddy, warm. So are people. Each person accumulates the rudiments of all human traits and can reveal either of them. It often happens that a person does not resemble himself being the same personality. (L.N. Tolstoy).

Task №2. Define the main (secondary) information.

Make a sentence with each key word. Put it down.

Task №3. Generalizing the characteristics.

Define the topic of the text and its main idea.

Entitle the text.

4. The fourth understanding technique is the determination of the author's thought activity situation.

One of the tasks can be the word's etymology study with the analysis of the etymological dictionary article. Let's consider the examples of tasks on this stage.

Task №1. Define the etymological meaning of the word “вода/water".

- Вoda/Water. Common Slavic. Indo-European. The same stem but with a vowel change is in the words ведро, выдра.

- Водка/Vodka. Russian. Derived from водa with the help of the suffix - ка. The primary meaning - "alcoholic medicinal tincture". The meaning "vodka" developed under the influence of the Polish wodka which is a free calk from the Latin aqua vitae - "alcohol" (literary - "water of life").

The learners can also analyse phraseological units with this word or word combination. The word "water" is represented in Russian phraseology and the students can be offered the following tasks:

Task №1. Read the given phraseological units. Define their meanings. Use them in the sentences of your own.

- Водой не разольёшь кого. Colloquial. Very friendly. Inseparable. Always together.

- Водой не разольёшь кого. Difficult to drive apart by force (us. about smb. fighting).

- Как, будто, словно, точно воды в рот набрал (-ла-ли). Colloq. Neg. Used with a subject with the meaning of a person. As if one has lost the ability to speak.

- Воды (водой) не замутит. Informal. Positive. Used with a subject with the meaning of a person. Very quiet, modest, gentle. Wouldn't hurt a fly.

- Возить воду на ком. Informal. Used with a subject with the meaning of a person. To burden s.o. with hard, demeaning work.

- Prov. На сердитых волу возят.

5. The fifth understanding technique is applied through phonetical, intonation, lexical and grammatical actualizations. At this stage the structure of the word and its role in the lexical meaning is comprehended. The learners work with key words and intonation. The following tasks are given:

Task №1. Find cognate words in the text. Define the meaning of each of them. Use them in phrases and sentences of your own.

Waterfall - water from a river falling over an edge of rock to a lower level. A waterfall is a place where the difference of levels is more than one meter. Lover are rapids and ledges. Angel Falls, the highest waterfall in the world, with the height of 979 meters, is situated in South America (Venezuela). A large wide waterfall usually not very high is 
called a cataract. The highest waterfall in Asia, the Talnikovy Waterfall (cascade), is situated in Russia on the Taimyr Peninsula on the Putorana Plateau.

Task №2. Add your own examples to the series of cognate words. A number of key words defined by the learners is given on the blackboard. Make a phrase with each word, make sentences, combine them in a text.

6. The sixth understanding technique is meaning reconstruction.

Task №1. Reconstruct the meaning of the text, use key words.

What is a waterfall - the highest waterfall - the height of the waterfall - cataract - the highest waterfall in Asia.

7. The seventh understanding technique is text individualization.

Questions. What is a waterfall? What waterfalls do you know? What is the height of the highest waterfall? What's the name of the highest waterfall in Asia? Where is it situated?

8. The eighth understanding technique is associating, finding and/or establishing links.

The learners may be given text reconstruction tasks. For example, they can be offered scattered pieces of a single text with the task to reconstruct the original text relying on associations and each piece understanding.

9. The ninth understanding technique is self-determination in the world of discerned meanings. A transition to a reflexive position, The reader faces the question: "I did understand. But what did I understand?".

Answer the questions: "What new information did I receive?", "How and where can I use it?".

10. The tenth understanding technique is evaluation of what has been understood. The learners evaluate the decree of conscious understanding of the information received.

11. The eleventh understanding technique is the transition to understanding evaluation: "Why did I understand it like this?".

The learners understand the text and, consequently, can find mistakes: "I understood this word correctly because it has several meanings, and is used in this very meaning in this text".

Task №1. How do you understand the phrase "so far"? (till now, till tomorrow, in the distant future, long past).

12. The twelfth understanding technique is innovation or inventing. This understanding technique is necessary not only to make a compressed secondary text, but also to complete creative tasks.

As an aide to deeper reading comprehension a number of text understanding techniques are applied. We rely on a system of understanding techniques that was offered by G.I. Bogin. Let's examine some of them. The first understanding technique is actualization of incomprehension, when points of incomprehension are determined. The process of understanding can result in comprehension of what has been read or in misunderstanding. In this case the reader assumes to have understood the text, but it is just a personal impression. That is why it is important for the reader to be able to assess his or her degree of understanding. The second technique is phenomenological reduction which mostly employs a critical and purifying function of reading and further understanding. The third technique is realization of prior experience, an ability to juxtapose old and new information. The application of the fourth understanding technique, which is determination of the situation of the author's activity of thought, allows the reader to master all types of situations represented in the texts. It might be a familiar situation (semantic understanding), object reality (cognitive understanding) and ideal reality (non-object understanding), which leads to a deeper comprehension of what has been read. Phonetic, intonation, lexical, grammatical and other actualizations also belong to understanding techniques and contribute to comprehension of sound and intonation aspects of the text. The process of understanding may be incomplete without other important techniques: 
meaning reconstruction by means of semantic knowledge, search for associations, construction of semantic relations, transition to reflection and evaluation of what has been understood [9].

\section{Methods}

The main methods employed in teaching reading comprehension include: analytical reading - a type of reading and text analysis oriented at the disclosure of the text content and structure, the study of its linguistic form, rational reading - reading and information analysis and interpretation. This type is based on a differential three stage algorithm with the first stage based on the search for key words, the second - semantic ranking (key words with their complements), the third - comprehension of the main idea of the text (O.M. Kazarceva, O.V. Vishnyakova) [10], hermeneutical analysis - a method of analytical interpretation based on the disclosure of the covert meanings of the text, reflection - a method of mental activity organization which recovers the means to achieve intellectual result (E.S. Antonova) [11].

The process of teaching text reading should be divided into four stages: 1) determination of the aim of reading (understanding why to read the text), 2) fact-finding reading (the author of the text, its title, the year and place of book publication, its content, preface, table of contents, etc.), 3) perception of meaning (the theme of the text, its main idea, etc.), 4) evaluation of the material which has been read (interesting/not interesting, known/unknown, useable information/unusable information, etc.) [12].

When teaching semantic reading, we suggest that special attention should be given to the following characteristics of such a process.

\section{Perception of signs: letters and words}

This is a physiological process based on immersion into the meaning through the sign form of speech. Even if the words have mistakes, but still resemble the words known to the reader, they are understood as familiar or are coordinated with them. The syntactic form of a phrase in the text is not always important. As a rule, meaning is of primary importance to the reader.

\section{Comprehension of meaning}

While getting acquainted with the text, the reader tries to attribute meaning to language structures, anticipates the content of the text, selects information in accordance with the context.

In the process of text perception, a person coordinates the received information with both the reality and his knowledge of this reality, thus choosing the most suitable variant from a number of options. In this way, the reader coordinates the text with the reality and turns it into the meaning lying beyond the sign form.

If a text has not been understood, e.g. a complicated scientific text, and the reader does not know the corresponding field of knowledge, he does not see the difference between objective feelings and the result of his perception. In other words, it is the stage of noncomprehension.

The process of getting acquainted with the text and its further comprehension is a process involving consecutive processing of information, which consists of several levels. If the reader needs to comprehend only letters, his perception is at the elementary level. The more complicated the text is, the more levels the process of semantic reading includes. 
The result of reading and understanding depends both on the object and on the perceiving subject. It is important for the reader to coordinate the received information with his life realities.

This feature is explained by the subjectivity of text perception. In this respect, a personality gets and processes information as an integral system with individual psychophysiologic, psychologic and social traits. An important role in the interaction of the reader with the text belongs to perception attitudes.

The first stage of functioning of such perception attitudes belongs to search operations, when the reader determines the source of a text message and makes a preliminary estimation of its possible informative value.

The second stage is perception, with the contact of the reader with the received information, the selection of data important for the comprehension of the meaning intertwined with the text. Only then can the obtained information be memorized.

An important role in developing reading comprehension (text understanding) belongs to a strategic approach. It gives the teachers the opportunity to modify the methodology of lesson conduction, to differentiate, individualize and intensify the learning process to a maximum degree, which is explained by the orientation of this approach at both individual and pair work.

The use of reading strategies makes text work at a lesson of the Russian language interactive, allowing altering the assignments of reading, speaking and writing. To implement this approach, learners must possess a number of specific strategies, which might facilitate the work with the text. Such strategies should not be considered as an algorithm consisting of a number of actions, since their implementation may involve deviations from the initial plan. "A strategy is not a mere application of a certain means based on a single rule. It is a group of actions and operations organized to reach the goal, subordinated to the movement to a common final goal" [13].

When comparing strategies and skills, Smetannikova noted that they "are in the same relations as process and result. Skills and competences are the result of teaching to read, while strategies are units belonging to the process", as the strategic approach teaches "to analyse, focus, choose, select, organize, integrate and use what is read, it develops and educates a thoughtful reader" [14].

The process of teaching reading and text comprehension should be divided into four stages: 1) determination of the aim of reading (understanding why to read the text), 2) factfinding reading (the author of the text, its title, the year and place of book publication, its content, preface, table of contents, etc.), 3) perception of meaning (the theme of the text, its main idea, etc.), 4) evaluation of the material which has been read (interesting/not interesting, known/unknown, useable information/unusable information, etc.).

This type of reading proficiency requires mastering school text understanding techniques. Such as:

- asking questions to the text,

- writing a plan of the text,

- designing flow charts,

- thesis writing,

- summary tables drawing,

- commentary writing [15].

A system of exercises facilitating the development of analytical reading skills was developed. The following types of exercises can be used at a lesson of the Russian language: illustrative (preparatory) exercises, comparative exercises, reconstruction exercises, construction exercises (revision and generalization), creative activity exercises. Below, each type is considered in greater detail: 
Let us look at the first type - illustrative (preparatory) exercises. Their main aim is to ensure primary text perception by the learners.

The second type is comparative exercises. The aim of these exercises is to acquaint the learners with examples of secondary texts (notes and theses), to determine the structure of secondary texts and to compare them with primary (original) texts. At this stage the learners analyse the given material: study the structure of the secondary text, find parts of the text and define their specific features.

Determining the structure of the secondary text includes:

1) explanation of the secondary text specific features in comparison with the primary text,

2) parts of the text identification and distinction: introduction, main part, conclusion,

3) parts of the text (introduction, main part, conclusion) specific features study,

4) words' contextual meaning explanation,

5) defining the meaning of each part in the general text structure,

6) dictionary use skills if necessary.

The third type is reconstruction exercises. Having done the tasks, the learners must consolidate the skills learning to modify the material, to write the introduction and the conclusion, to modify the information. On the word level, they learn to work with word meanings, to find synonyms and antonyms to the word from the text. These exercises develop the skills of working with language material: synonym and antonym selection. On the sentence level, schoolchildren develop information modification skills. When working with parts of the text (paragraphs, introduction, conclusion), the learners understand and learn to explain the subdivision to paragraphs, to find the introduction and the conclusion.

The fourth type is construction exercises (revision and generalization). Their aim is to facilitate the information intake. Such exercises include the following:

1) paragraph subdivision of the text,

2) finding examples by the learners illustrating the use of the word in certain meaning,

3) making sentences with the transformation of the primary information,

4) information compression: writing a thesis to part of the text,

5) text title selection, entitling the text,

6) editing.

The fifth type is creative exercises that suggest text production. Among these:

1) making up sentences summarizing the information of the given text (orally and in the written form),

2) making a single text from several variants with identical information,

3) writing a variant of introduction and conclusion,

4) compression of the information of each paragraph to a thesis.

5) secondary texts writing (theses, a summary).

To achieve a deeper understanding of the text, the following exercises aimed at understanding the text structure are recommended: 1) studying the text structure: introduction, conclusion, paragraphs, 2) studying specific features of individual text sections: introductions, conclusions, paragraphs, 3) studying the placement of information in the text, reconstruction of the correct information order, 4) title selection exercises (suggesting possible titles) to a part of the text or the whole text, 5) writing sentences summarizing information in various text sections.

We use a system of exercises that facilitate a deeper reading understanding. This system includes: illustrative exercises, their aim is to demonstrate the semantic meaning of the word and to build a primary non-contextual idea of the word, comparative exercises which by means of comparison, analysis and generalization enable the students to determine general and specific features of language units, reconstruction exercises which form the skill to draw information from various sources, to make generalizations, to build a logical sequence of reasoning, to select arguments, revision and generalization exercises lead to 
the understanding of word polysemy, introduce the word into the active lexical fund of school children, creative activity exercises focus at the use of the language material in speech, teach to express one's opinion on the given subject [16].

\section{Conclusion}

Adequate text understanding teaching is one of the most important issues in modern methodology. Written text comprehension enables the reader to understand the author's motives to write the way he writes and to comprehend the inner logics of the author's text message. This level of understanding can be reached by meticulous teaching work focused on a deeper immersion into the text.

\section{References}

1. E.G. Azimov, A.N. Schukin, Novyj slovar' metodicheskih terminov i ponyatij (teoriya $i$ praktika obucheniya yazykam) (M., Izdatel'stvo IKAR, 2009)

2. I.A. Zimnyaya, Lingvopsihologiya rechevoj deyatel'nosti (M., MPSI, Voronezh: NPO "MODEK", 2001)

3. N.I. Zhinkin, Mekhanizmy rechi (M., Izd-vo APN RSFSR, 1958)

4. M.M. Bahtin, Estetika slovesnogo tvorchestva (M., Iskusstvo, 1979)

5. N.V. Kulibina, Hudozhestvennyj tekst v lingvodidakticheskom osmyslenii: dis. ... doktora pedagogicheskih nauk (Moscow, Gos. in-t rus. yaz. im. A.S. Pushkina, 2001)

6. I.F. Annenskij, Pervye shagi v izuchenii slovesnosti (SPb, 1888)

7. G.I. Bogin, Tipologiya ponimaniya teksta: ucheb. posobie (Kalinin, Izd-vo KGU, 1986)

8. I.V. Tekucheva, L.Y. Gromova, Srednee professional'noe obrazovanie 11, 59 (2016)

9. G.I. Bogin, Filologicheskaya germenevtika (Kalinin, Izd-vo KGU, 1982)

10. O.M. Kazarceva, O.V. Vishnyakova, Pis'mennaya rech': ucheb. posobie dlya uchashchihsya 10-11 kl. i abiturientov (M., Flinta: Nauka, 1998)

11. E.S. Antonova, Metodika prepodavaniya russkogo yazyka: kommunikativnodeyatel'nostnyj podhod: ucheb. posobie dlya studentov ped. ucheb. zavedenij (grif UMO) (M., KnoRus, 2007)

12. L.N. V'yushkova, Russkij yazyk v shkole 1, 3 (1998)

13. N.N. Smetannikova, A strategic approach to teaching reading (interdisciplinary problems of reading and literacy) (Moscow, School library, 2005)

14. 14 N.N. Smetannikova, Reading leaders teaching strategy (M.: ZAO «RIC «MDK», 2007)

15. G.V. Prantsova, E.S. Romanicheva, Modern reading strategies: theory and practice. Semantic reading and text work: teaching manual (M., Forum, 2015)

16. L.Y. Gromova, Sovremennye tendencii v razvitii metodiki prepodavaniya russkogo yazyka: kollektivnaya monografiya (M., Sputnik+, 2017) 